\title{
The positive impact of platelet-derived growth factor on the repair of full-thickness defects of articular cartilage
}

\author{
Trombosit türevli büyüme faktörünün tam kat eklem kıkırdağı defektlerinin \\ tamirine pozitif etkisi
}

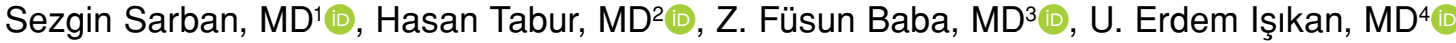 \\ 'Department of Orthopedics and Traumatology, Acıbadem Mehmet Ali Aydınlar University, İstanbul, Turkey \\ ${ }^{2}$ Department of Orthopedics and Traumatology, Gaziantep State Hospital, Gaziantep, Turkey \\ ${ }^{3}$ Department of Pathology, Acıbadem Maslak Hospital, İstanbul, Turkey \\ ${ }^{4}$ Department of Orthopedics and Traumatology, Harran University Faculty of Medicine, Şanlıurfa, Turkey
}

\begin{abstract}
Objectives: This study aims to investigate the potential use and histological effects of the local administration of platelet-derived growth factor (PDGF) in the repair of full-thickness osteochondral defects in articular cartilage in an animal model.
\end{abstract}

Materials and methods: Twenty-four adolescent 18-week-old New Zealand White rabbits with an average weight of $2500 \mathrm{~g}$ (range, $1600 \mathrm{~g}$ to $3200 \mathrm{~g}$ ) were used in the study. The rabbits were randomly divided into three groups $(\mathrm{n}=8)$ as the control group (group A) and two experimental groups (groups B and C). Defects of cylindrical full-thickness (3.5 $\mathrm{mm}$ wide, $4 \mathrm{~mm}$ deep) were created in the weight-bearing area of the right knee medial femoral condyles. In group A, the defect was left empty. In group B, the defect was filled with a collagen sponge. In group $\mathrm{C}$, the defect was filled with a collagen sponge impregnated with PDGF. All rabbits were followed-up for 12 weeks. Right knee medial femoral condyles were used for macroscopic and histological analyses.

Results: At macroscopic level, the repair tissue was similar to normal adjacent cartilage at 12 weeks in group $\mathrm{C}$. The surface of the repair tissue in group $\mathrm{C}$ was smoother and more regular compared to groups $\mathrm{A}$ and $\mathrm{B}$. The total histological score of defects in group $\mathrm{C}$ was statistically significantly superior compared to groups A and B $(\mathrm{p}<0.05)$. Matrix staining and immunostaining of collagen type 2 were stronger in group C compared to the other groups, indicating the presence of a tissue similar to a normal cartilage.

Conclusion: Platelet-derived growth factor can induce repair in full-thickness defects of articular cartilage in an animal model. Thus, this study demonstrates the potential use of PDGF for full-thickness osteochondral defects.

Keywords: Articular cartilage, full-thickness defects, platelet-derived growth factor.

\section{ÖZ}

Amaç: $\mathrm{Bu}$ çalışmada lokal trombosit türevli büyüme faktörü (TTBF) uygulamasının tam kat eklem kıkırdağının osteokondral defektlerinin tamirinde potansiyel kullanımı ve histolojik etkileri bir hayvan modelinde araştırıldı.

Gereç ve yöntemler: Çalışmada ortalama ağırlığı $2500 \mathrm{~g}$ (dağılım, 1600 g-3000 g) olan adölesan 18 haftalık 24 Yeni Zelanda Beyaz tavşanı kullanıldı. Tavşanlar kontrol grubu (grup A) ve iki deneysel grup (grup B ve C) olmak üzere randomize olarak üç gruba $(n=8)$ ayrıldı. Sağ diz medial femoral kondillerin yük taşıyan alanında tam kat silindirik defektler (3.5 mm eninde, $4 \mathrm{~mm}$ derinliğinde) oluşturuldu. Grup A'da defekt boş bırakıldı. Grup B'de defekt kollajen süngerle dolduruldu. Grup C'de defekt TTBF emdirilmiş kollajen süngerle dolduruldu. Tüm tavşanlar 12 hafta takip edildi. Să̆ diz medial femoral kondiller makroskopik ve histolojik analizler için kullanıldı.

Bulgular: Grup C'de makroskopik düzeyde 12 haftada tamir dokusu bitişik normal kıkırdağa benzerdi. Grup C'de tamir dokusunun yüzeyi grup A ve B'ye göre daha düz ve düzenliydi. Grup C'de defektlerin toplam histolojik skoru grup A ve B'ye kıyasla istatistiksel olarak anlamlı şekilde daha iyiydi $(\mathrm{p}<0.05)$. Grup C'de matriks boyaması ve kollajen tip 2'ye ait immün boyama normal kıkırdağa benzer bir doku yapısının göstergesi olarak diğer gruplara göre daha kuvvetliydi.

Sonuç: Trombosit türevli büyüme faktörü hayvan modelinde tam kat eklem kıkırdağı defektlerinin tamirini uyarabilir. Dolayısıyla, bu çalışma TTBF'nin tam kat osteokondral defektlerde potansiyel kullanımına işaret etmektedir.

Anahtar sözcükler: Eklem kıkırdağı, tam kat defektler, trombosit türevli büyüme faktörü.

Received: December 18, 2018 Accepted: May 19, 2019 Published online: June 13, 2019

Correspondence: Sezgin Sarban, MD. Acıbadem International Hastanesi Ortopedi ve Travmatoloji Bölümü, 34149 Bakırköy, İstanbul, Turkey. Tel: +90 212 - 4684069 e-mail: sezgin.sarban@acibadem.edu.tr 
The healing of articular cartilage is limited after a defect caused by trauma or osteoarthritis. Higher percentages of fibrous cartilage instead of hyaline cartilage are generated during the repair process of a full-thickness defect, which leads to a repair tissue that is biomechanically less resistant. Importantly, cells such as chondroblasts and chondrocytes in the repair tissue are produced by mesenchymal stem cells (MSCs) moving from the marrow. ${ }^{[1,2]}$ This process, also known as neochondrogenesis, is one of the most studied areas in recent years. Studies on skeleton metabolism have led to the identification of a number of factors involved in the cartilage formation by causing the differentiation of MSCs into chondrocytes. ${ }^{[1,2]}$

Growth factors such as recombinant human bone morphogenetic protein 2 (rhBMP-2), insulin-like growth factor-1 (IGF-1) and basic fibroblast growth factor (bFGF) play a role in the repair of full-thickness defect by increasing the ratio of collagen type 2 which leads to the increased mechanical strength of cartilage. ${ }^{[3-5]}$ Studies have shown that transforming growth factor-beta (TGF- $\beta$ ) promotes cartilage differentiation of bone marrow MSCs in vitro and in vivo. ${ }^{[6]}$

Platelet-derived growth factor (PDGF) can exist as homo- or heterodimer. Platelet-derived growth factor is a significant mitogenic and chemotactic growth factor for cells of mesenchymal origin such as chondrocytes and MSCs. Reports have shown that PDGF increases the proliferation and proteoglycan production of resting zone chondrocytes and stimulate meniscal cell proliferation and migration..$^{[7,8]}$

Only a few studies have focused on the role of PDGF on the repair of full-thickness defect in articular cartilage in vivo. However, to our knowledge, there is no study on the efficacy of collagen sponge impregnated with PDGF in the repair of full-thickness defect. Therefore, in this study, we aimed to investigate the potential use and histological effects of the local administration of PDGF in the repair of full-thickness osteochondral defects in articular cartilage in an animal model.

\section{MATERIALS AND METHODS}

This study was conducted at Harran University Faculty of Medicine between March 2006 and June 2006 and included 24 adolescent 18-week-old New Zealand white rabbits with an average weight of $2500 \mathrm{~g}$ (range, $1600 \mathrm{~g}$ to $3200 \mathrm{~g}$ ). The rabbits were divided into three groups $(\mathrm{n}=8)$ including the control group (group A) and two experimental groups (groups B and C). The ethic regulations have been

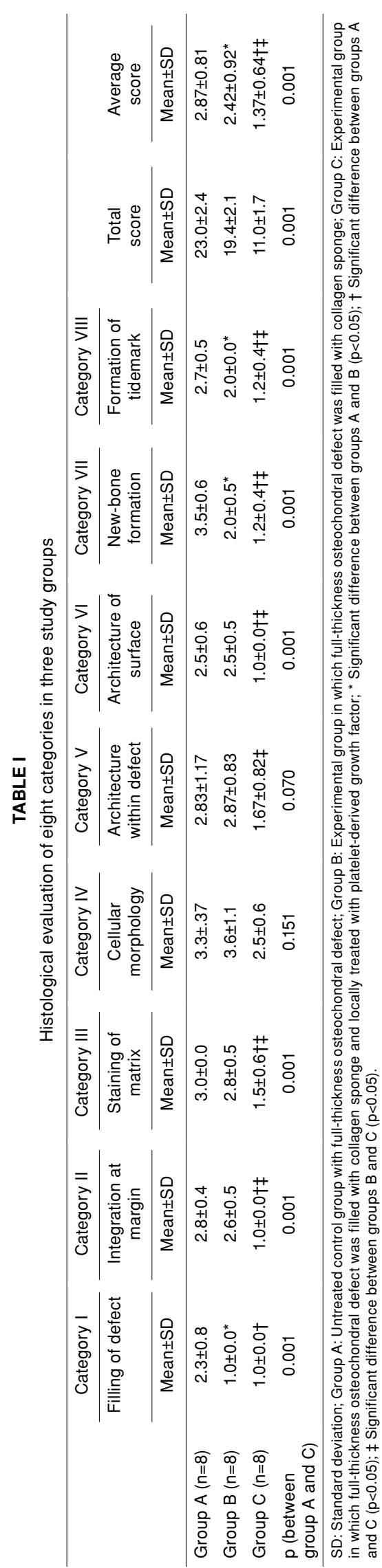


followed according to the international, national and institutional guidelines. All experimental protocols were approved by the Harran University Ethics Committee for Experimental Animal Research [06.02.2006 (2006/410)].

The right knee joint was approached through a $3 \mathrm{~cm}$ medial parapatellar incision under sterile conditions. The patella was dislocated laterally by medial arthrotomy to expose the articular surface. A full-thickness defect $(3.5 \mathrm{~mm}$ in diameter, $4 \mathrm{~mm}$ in depth) was generated in the medial femoral condyle in the weight-bearing area, using a hand perforator with a $3.5 \mathrm{~mm}$ diameter drill-bit, as previously described.$^{[9]}$ The joint capsule was closed by precise suturing. In group $A$, the defect was left empty. In group B, the defect was filled with a collagen sponge. In group $C$, the defect was filled with collagen sponge impregnated with $62.5 \mathrm{ng}$ of human PDGF (Sigma-Aldrich ${ }^{\circledR}$ Catalog no: P-8147, St. Louis, MO, USA). After surgery, all animals were allowed to move freely in their cages. All rabbits were sacrificed at 12 weeks after surgery by intravenous injection of $7.5 \%$ potassium chloride.

Right knee femoral condyles were obtained from all sacrificed animals. Defects were photographed and investigated macroscopically. Samples were placed into $10 \%$ buffered formalin, decalcified and paraffinized. Sections of $4 \mu \mathrm{m}$ were cut and stained with hematoxylin-eosin. Cartilage matrix was stained with toluidine blue (TB). Periphery of the defect was compared with the normal tissue. A collagen type 2 specific antibody (Ab-2, Neomarkers ${ }^{\circledR}$, Fremont, CA, USA) was used for immunostaining.

The modified histological scale from Sellers et al. ${ }^{[4]}$ was used for scoring. ${ }^{[4]}$ The scoring system consists of eight different categories (Table I) with a total score ranging from 0 points (normal cartilage) to 31 points (no repair tissue). The eight categories used for evaluation are as follows: ${ }^{[4]}$ Filling of defect relative to surface of normal adjacent cartilage; integration of repair tissue with surrounding articular cartilage;
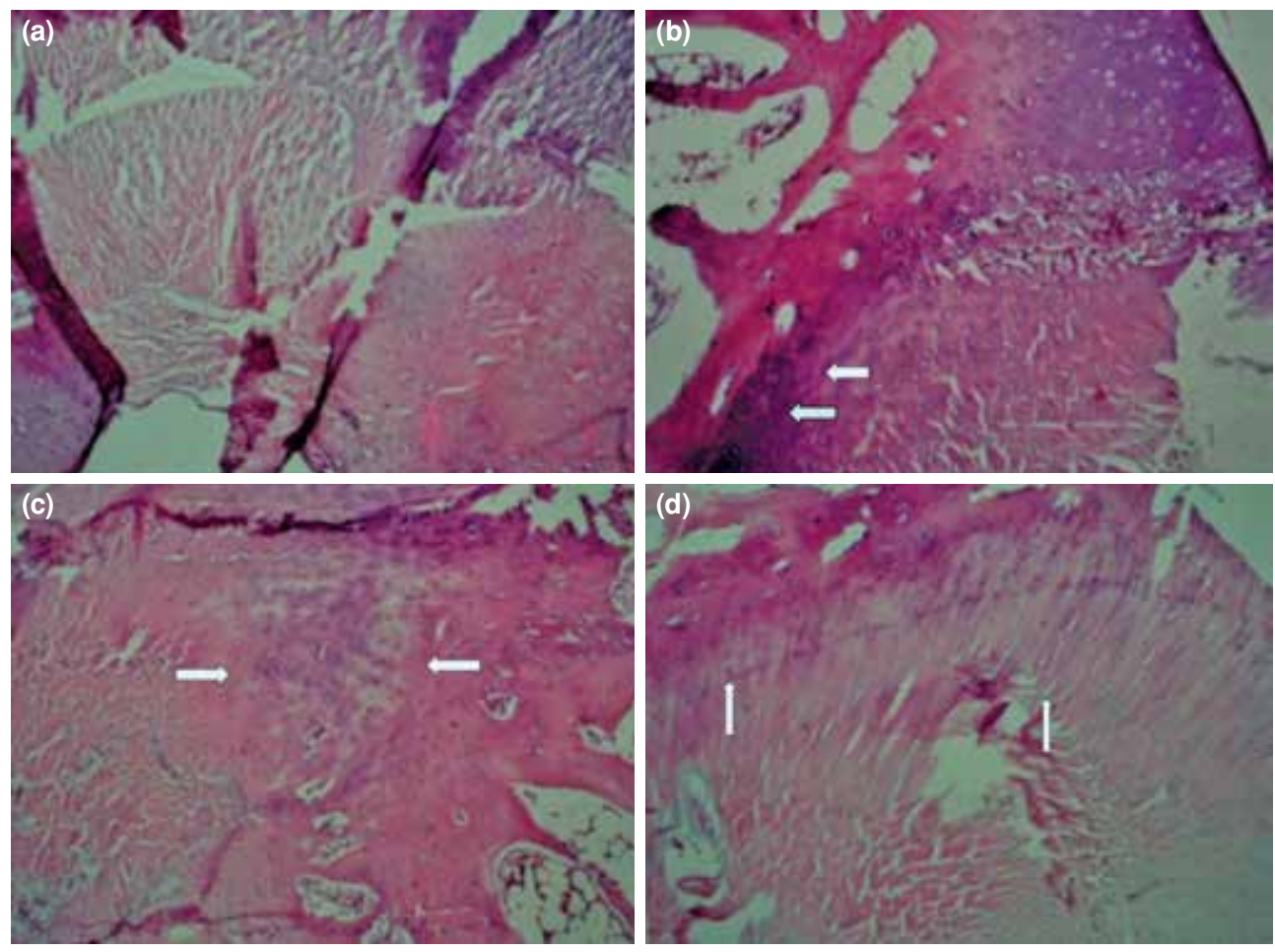

Figure 1. Immunohistochemical analyses of repair system. Hematoxylin-eosin staining of repair tissue at 12 weeks $(\mathrm{H}-\mathrm{E} \times 40)$. (a) In group $\mathrm{A}$, defect was filled with a fibrocartilaginous tissue with mostly round cells with morphology of chondrocytes. (b) In group B, defect was filled with mostly round cells with morphology of chondrocytes, $<25 \%$ of tissue with columns in radial zone (disorganized). (c) In group C, defect was filled with mostly round cells with morphology of chondrocytes, $<25 \%$ of tissue with columns in radial zone (disorganized). (d) In group C, defect was filled with mostly round cells with the morphology of chondrocytes, $25-75 \%$ of tissue with columns in radial zone. Images representative from eight animals in groups $A, B$ and $C$. 
matrix staining; cellular morphology; architecture within the entire defect; architecture of surface; percentage of new subchondral bone and formation of tidemark. The Olympus CH40 microscope ( Olympus Microscope, Tokyo, Japan) was used to evaluate the specimens.

\section{Statistical analysis}

All statistical analyses were performed using the Statistical Package for the Social Sciences (SPSS) version 11.0 for Windows (SPSS Inc., Chicago, IL, USA) software. The histopathological differences were analyzed by Kruskal-Wallis test. Mann-Whitney $\mathrm{U}$ test was used to identify the differences between various treatment groups. A $p$ value of $\leq 0.05$ was considered statistically significant.

\section{RESULTS}

Macroscopic properties of the defect were examined in all groups. At 12 weeks, the color of repair tissue in group A was between white and purple and had an irregular surface. In contrast, the color and structure of the repair cartilage were similar to the adjacent normal cartilage in groups $\mathrm{B}$ and $\mathrm{C}$.
Defects were mostly filled with cartilage areas and there was a good continuity with normal cartilage. The color of repair tissue was cloudy white. The surface of the repair tissue in group $C$ was smoother and more regular compared to groups $\mathrm{A}$ and $\mathrm{B}$.

Sections taken from the center of the defect were used for the evaluation (Figure 1). Histological evaluations from the center of the defect revealed that most of the categories were significantly different between group A and groups B and C in all categories except categories 4 and 5 (Table I). Categories 1, 7 and 8 were significantly different between groups $A$ and $B$, while no significant difference was found for categories 2, 3, 4, 5 and 6 (Table I). Groups A and C were significantly different for most categories except for categories 4 and 5 (Table I). Groups B and C were also significantly different for most categories except for categories 1 and 4 (Table I). Toluidine blue staining was used to stain cartilage matrix. There was little matrix staining in the repair tissue compared to adjacent normal cartilage in group A. In group B, matrix staining was at the medium level. In group $\mathrm{C}$, the
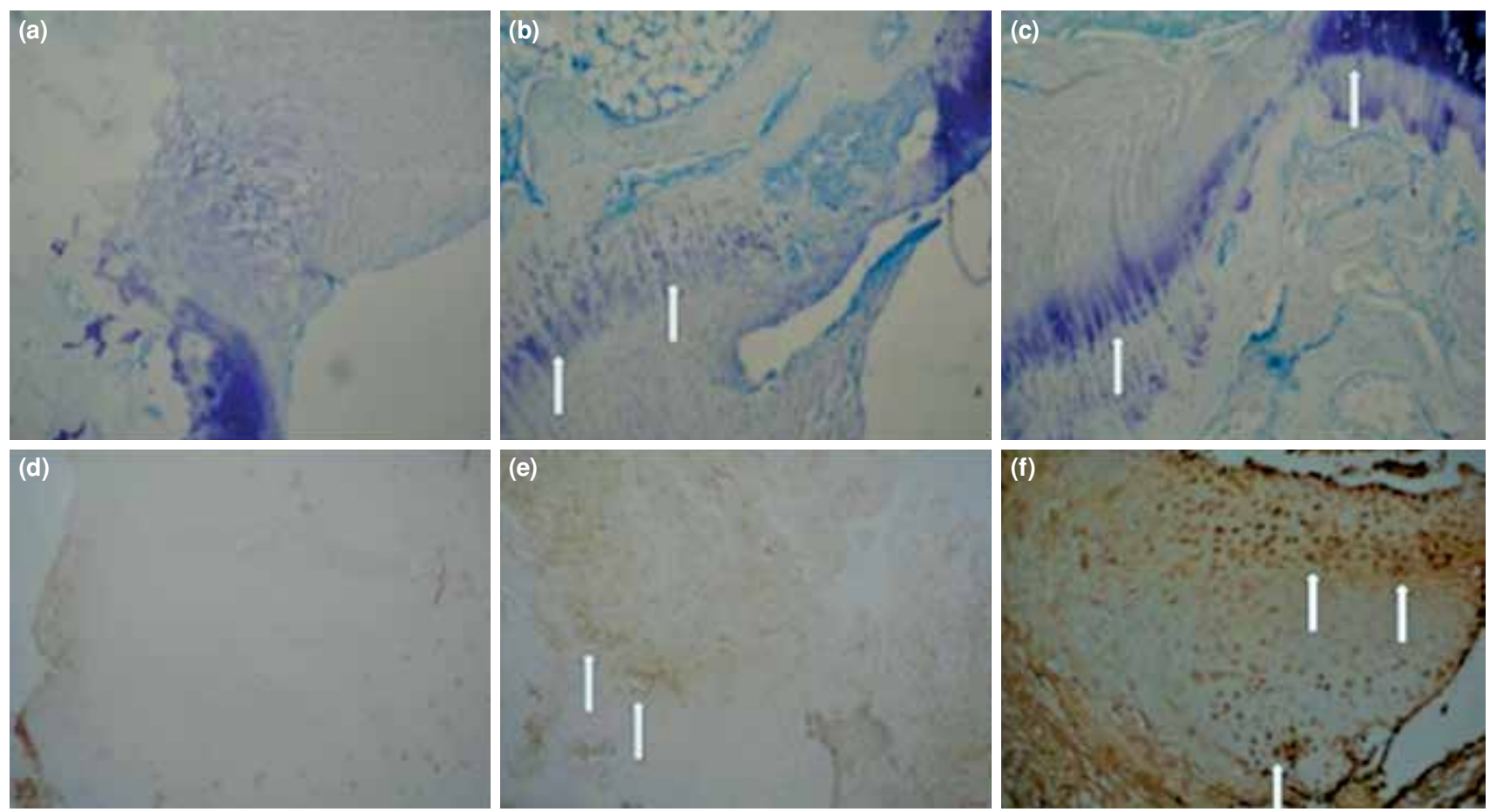

Figure 2. (a) Toluidine blue (TB) staining for matrix. There is very little matrix staining in newly formed fibrocartilaginous tissue in group $A(T B \times 40)$. (b) In group B, medium level of matrix staining in chondrocytes that cover $25-75 \%$ of tissue with columns in radial zone $(T B \times 40)$. (c) Strong matrix staining in group $C(T B \times 40)$. (d) Immunostaining for collagen type 2 . There is little staining in group $A$ (Collagen type $2 \times 40$ ). (e) Immunostaining for collagen type 2 . In group $B$, chondrocytes are disorganized and only a small portion of them are in radial columns. There is a medium level collagen type 2 expression in these chondrocytes (Collagen type $2 \times 40$ ). (f) Immunostaining for collagen type 2. There is strong intracytoplasmic collagen type 2 expression in chondrocytes that are mostly in radial columns (Collagen type $2 \times 40$ ). 
matrix staining in the repair tissue was close to the level in the adjacent normal cartilage (Figure 2a, b and $c$, respectively). Collagen type 2 staining was not present in group A whereas a weak to medium staining was found in group B and a medium to strong staining was present in group C. There was intra-cytoplasmic staining in group $\mathrm{C}$ as well (Figure 2d, e and f, respectively).

\section{DISCUSSION}

This study showed that the local administration of $62.5 \mathrm{ng}$ of PDGF in a collagen sponge led to macroscopic and histological improvement in full-thickness osteochondral defect. In group C (PDGF-treated animals), total histological score was significantly lower than group A (control animals) (total score: group A, 23.00 \pm 2.37 ; group C, $11.00 \pm 1.67$; $\mathrm{p}<0.001)$. Sellers et al. ${ }^{[4]}$ showed that total histological score was $8.6 \pm 4.1$ and $9 \pm 2.71$ in rhBMP-2 treated experimental groups at six months and in one year, respectively. They also showed that total histological score was $14.30 \pm 5.58$ in control group in one year $(\mathrm{p}<0.05)^{[4,10]}$ Tuncel et al. ${ }^{[5]}$ demonstrated that the IGF1-treated group had a mean histological score of 5.5 (range, 4 to 9) whereas the mean score of the control group was 12 (range, 8 to 17$)$ at 12 weeks $(\mathrm{p}<0.05)$. In another study, bFGF induced cartilage healing with a histological score of 3 in the treated group compared to a histological score of 6 in the control group at the end of 12 weeks. ${ }^{[11]}$ In these studies, growth factors other than PDGF have been studied and shown to be efficient. In our study, PDGF has shown a comparable level of efficacy at 12 weeks.

In our study, collagen type 2 staining, which is known to increase the resistance of articular cartilage, was intense in repaired defects of group $C$, whereas a medium level of immunostaining for collagen type 2 was found in group B. Tuncel et al. ${ }^{[5]}$ showed increased collagen type 2 immunostaining in rabbit joints treated locally with IGF-1 at 12 weeks after defect formation. In their study with bFGF, Fujimato et al. ${ }^{[3]}$ showed immunostaining of collagen type 2 both in the surface and deeper regions of the repaired tissue in the control group at one year after the defect formation.

Platelet-derived growth factor injected into the articular joint of growing rats caused an early, transitory induction of the osteogenic activity in the zone between cartilage and red bone marrow. ${ }^{[12]}$ Several studies have focused on the molecular and cellular mechanisms of the effect of PDGF on chondrocyte cells. Schmidt et al. ${ }^{[8]}$ demonstrated that PDGF two B chains (PDGF-BB) induced chondrocyte proliferation at dose between 4.7 and $300 \mathrm{ng}$. In our study, a PDGF $A$ and $B$ chains (PDGF-AB) heterodimer was used. A mixture of TGF- $\beta 1$, bFGF and PDGF supplementation allowed the increase of the chondrogenic potential of costochondral cells in vitro, which was demonstrated by enhanced type 2 collagen ratio and compressive properties. ${ }^{[13]}$ Furthermore, PDGF can also regulate chondrocyte proliferation through extracellular signal-regulated kinase 1/2 (ERK1/2) pathway. ${ }^{[14]}$ These studies give an idea about molecular networks in which PDGF has a role and suggest a molecular mechanism of action for the role of PDGF in the repair of cartilage in our animal model.

Yokoyama et al. ${ }^{[15]}$ showed that platelet-activated serum had a positive impact on the repair of articular cartilage in rabbits subjected to anterior cruciate ligament transection. They demonstrated that platelet-activated serum had high levels of vascular endothelial growth factor (VEGF), PDGF-BB and TGF- $\beta$. In another study, an osteochondral defect (size of 10x6 mm) was created in femoral condyles of pigs by Betsch et al. ${ }^{[16]}$ Bone marrow aspiration concentrate and platelet rich plasma (PRP) were found to cause a significant improvement in the defect repair histologically. Platelet rich plasma had high levels of growth factors such as bone morphogenetic protein 2 (BMP-2), BMP-7, VEGF, TGF- $\beta 1$ and PDGF. ${ }^{[16]}$ In these studies, growth-factor enriched materials such as platelet activated serum or PRP were used and a therapeutic effect was shown. Although one of the factors enriched was PDGF, the effect was most probably due to the combination of these factors. On the other hand, our study focused on the use of PDGF alone in a collagen sponge as a scaffold. Therefore, our study is different from these studies as it shows individual activity of PDGF in a collagen sponge scaffold. ${ }^{[17]}$ In a clinical study, the PDGF concentration was significantly higher in anterior cruciate ligament reconstructed knee group than in the meniscectomy group and correlated with a higher healing rate of the meniscus. Therefore, it has been suggested that PDGF may have a critical role in the healing response of meniscus suture. ${ }^{[18]}$ In a clinical study focusing on PDGF, five patients with an isolated osteochondral defect were treated with recombinant human PDGF in a matrix of tricalcium phosphate after arthroscopic debridement. The mean weightbearing visual analog scale pain score and the mean osteoarthritis scale functional score improved. Bone healing was observed by computed tomography. ${ }^{[19]}$ This study puts emphasis on the role of PDGF alone in the repair of osteochondral defects in patients. Our study is different from this study as it has been 
performed in an animal model using a different scaffold, collagen sponge. Moreover, repair tissue was investigated histologically in our study, which would not be feasible in a study with patients in the clinic.

A limitation of our study was having a single time point, which was 12 weeks. Having multiple time points with an increased number of animals would make our study stronger. A 12-week period was considered as the minimum time period for the repair of cartilage. As a matter of fact, we observed the formation of hyaline-like cartilage and collagen type 2 in this time period.

In conclusion, to the best of our knowledge, only a few studies have focused on the use of PDGF for the repair of articular cartilage in animal models. Our study demonstrates the potential use of locally applied PDGF in a collagen sponge for full-thickness osteochondral defects. The dose of PDGF may be standardized in experimental models and PDGF may become an appropriate treatment for osteochondral defects in clinical setting.

\section{Acknowledgements}

The authors thank Dr. Sinan Zehir of Hitit University for conducting the surgeries and Dr. Mehmet Eskin of Koc University for the statistical analysis.

\section{Declaration of conflicting interests}

The authors declared no conflicts of interest with respect to the authorship and/or publication of this article.

\section{Funding}

This project was partly supported by Harran University Research Fund (HUBAK 410). Kurtsan Inc. (Istanbul, Turkey) supplied the absorbable collagen sponges for this study.

\section{REFERENCES}

1. Furukawa T, Eyre DR, Koide S, Glimcher MJ. Biochemical studies on repair cartilage resurfacing experimental defects in the rabbit knee. J Bone Joint Surg [Am] 1980;62:79-89.

2. Shapiro F, Koide S, Glimcher MJ. Cell origin and differentiation in the repair of full-thickness defects of articular cartilage. J Bone Joint Surg [Am] 1993;75:532-53.

3. Fujimoto E, Ochi M, Kato Y, Mochizuki Y, Sumen Y, Ikuta $Y$. Beneficial effect of basic fibroblast growth factor on the repair of full-thickness defects in rabbit articular cartilage. Arch Orthop Trauma Surg 1999;119:139-45.

4. Sellers RS, Peluso D, Morris EA. The effect of recombinant human bone morphogenetic protein-2 (rhBMP-2) on the healing of full-thickness defects of articular cartilage. J Bone Joint Surg Am 1997;79:1452-63.

5. Tuncel M, Halici M, Canoz O, Yildirim Turk C, Oner M, Ozturk F, et al. Role of insulin like growth factor-I in repair response in immature cartilage. Knee 2005;12:113-9.

6. Zhang YD, Zhao SC, Zhu ZS, Wang YF, Liu JX, Zhang ZC, et al. Cx43- and Smad-Mediated TGF- $\beta$ / BMP Signaling Pathway Promotes Cartilage Differentiation of Bone Marrow Mesenchymal Stem Cells and Inhibits Osteoblast Differentiation. Cell Physiol Biochem 2017;42:1277-93.

7. Fortier LA, Barker JU, Strauss EJ, McCarrel TM, Cole BJ. The role of growth factors in cartilage repair. Clin Orthop Relat Res 2011;469:2706-15.

8. Schmidt MB, Chen EH, Lynch SE. A review of the effects of insulin-like growth factor and platelet derived growth factor on in vivo cartilage healing and repair. Osteoarthritis Cartilage 2006;14:403-12.

9. Messner K, Gillquist J. Cartilage repair. A critical review. Acta Orthop Scand 1996;67:523-9.

10. Sellers RS, Zhang R, Glasson SS, Kim HD, Peluso D, D'Augusta DA, et al. Repair of articular cartilage defects one year after treatment with recombinant human bone morphogenetic protein-2 (rhBMP-2). J Bone Joint Surg [Am] 2000;82:151-60.

11. Argün M, Öner M, Güney A, Halıcı M, Temizyürek O, Canöz Ö. The healing of full-thickness articular cartilage defects in rabbits: successful results with fibroblast growth factor. Eklem Hastalik Cerrahisi 2010;21:147-52.

12. Hulth A, Johnell O, Miyazono K, Lindberg L, Heinegård D, Heldin $\mathrm{CH}$. Effect of transforming growth factor-beta and platelet-derived growth factor-BB on articular cartilage in rats. J Orthop Res 1996;14:547-53.

13. Murphy MK, Huey DJ, Reimer AJ, Hu JC, Athanasiou KA. Enhancing post-expansion chondrogenic potential of costochondral cells in self-assembled neocartilage. PLoS One 2013;8:e56983

14. Xiao J, Chen X, Xu L, Zhang Y, Yin Q, Wang F. Regulation of chondrocyte proliferation through GIT1-Rac1-mediated ERK1/2 pathway by PDGF. Cell Biol Int 2014;38:695-701.

15. Yokoyama M, Sato M, Tani Y, Yokoyama M, Kokubo M, Yamato $\mathrm{M}$, et al. Platelet-activated serum might have a therapeutic effect on damaged articular cartilage. J Tissue Eng Regen Med 2017;11:3305-12.

16. Betsch M, Schneppendahl J, Thuns S, Herten M, Sager M, Jungbluth $\mathrm{P}$, et al. Bone marrow aspiration concentrate and platelet rich plasma for osteochondral repair in a porcine osteochondral defect model. PLoS One 2013;8:e71602.

17. Sezgin EA, Atik OŞ. Are orthobiologics the next chapter in clinical orthopedics? A literature review. Eklem Hastalik Cerrahisi 2018;29:110-6.

18. de Girolamo L, Galliera E, Volpi P, Denti M, Dogliotti G, Quaglia A, et al. Why menisci show higher healing rate when repaired during ACL reconstruction? Growth factors release can be the explanation. Knee Surg Sports Traumatol Arthrosc 2015;23:90-6.

19. Younger A, Wing K, Penner M, Cresswell M. A study to evaluate the safety of platelet-derived growth factor for treatment of osteochondral defects of the talus. Knee Surg Sports Traumatol Arthrosc 2016;24:1250-8. 